Terrien, F.-Des troubles visuels provoqués par l'électricité. La Presse Med., March 6, 1912.

Vogt, A.-Recherches expérimentales sur la pénétrabilité des rayons infra-rouges à travers les milieus transparents de l'oeil. Arch.f. Ophtal., p. 155, 1912.

Gibbs, H. D.-Effets du soleil tropical sur l'homme et quelques animaux. Rev. gén. des Sci., p. 689, 1912.

Parsons, J. H.-Affections de l'oeil produites par l'exposition à la lumière excessive. Rapport Cong. Internat. de Méd. de Londres, Sect. d'Ophtal., August 6-12, 1913.

Moreau, F.-Ophtalmie électrique. Ann.d'Ocul., p. 351, 1916.

Roy, J. N.-De la vision chez les noirs de l'Afrique, Ann. d'Ocul., OctoberNovember, 1918.

Chappé.-Conjonctivite chez les artistes de cinéma. Ann. d'Ocul., July, 1920.

Roy, J. N.-Des affections oculaires dans la syphilis et la trypanosomiase humaine chez les indigènes de l'Afrique. Ann. d'Ocul., March, 1921.

Ginella.-Production de la cataracte par les infra-rouges. Arch. f. Ophthal., p. $483,1924$.

Müller, H.-Lésions oculaires par les rayons infra-rouges. Arch. f.Ophthal., p. 503, 1924.

Toulant, P.-Les rayons ultra-violets en ophtalmologie. Action sur le segment antérieur de l'oeil. Les Presses Univer. de France, Paris, 1926.

Roy, J. N.-L'éblouissement électrique. Quelques considérations médico-légales. Ann. d'Ocul., June, 1928.

\title{
HYPOPYON ULCER OF THE CORNEA DUE TO GLENOSPORA GRAPHII
}

\author{
BY \\ LT.-CoL. R. E. WRIGHT \\ PROFESSOR OF OPHTHALMOLOGY, MEDICAL COLLEGE, AND \\ SUPERINTENDENT, GOVERNMENT OPHTHALMIC HOSPITAL, MADRAS
}

N., a Hindu female, aged 38 years, presented herself on August 14, 1928 , with a hypopyon ulcer of the cornea. The lesion wais round, about $3 \mathrm{~mm}$. in diameter, situated in the centre of the inferior quadrant. An observer at first sight might have accepted the case as an ordinary ulcer with hypopyon, although there was a difference, which, without going into tedious detail, might be summed up by saying that the whole picture was more indolent than the usual hypopyon ulcer, using the word in its ordinary surgical sense. There was one feature, however, which could not have escaped the eye of an alert ophthalmologist: the floor of the ulcer was filled in by a tough slough, so that when one explored it with a suitably pointed piece of match wood soaked in pure carbolic, it was possible to demonstrate a slightly undermined edge, a gutter of demarcation, and a greyish yellow, and tightly adherent, central mass. After preliminary surgical cleaning of the conjunctival sac and superficial sterilisation of the slough, the latter was firmly seized in suitable forceps and removed with some difficulty. It was broken up in a sterilised Petri dish and cultures made at once on Sabouraud's medium. Under the microscope a dense mass showing an indistinct mycelium was observed, about which there was 
nothing informative to be made out. Some pure cultures of the mould were obtained and sent for identification to Lt.-Col. H. W. Acton, I.M.S., Professor of Pathology and Bacteriology, and Director, School of Tropical Medicine and Hygiene, Calcutta, who was working on the pathogenic fungi. His report is given below.

The history of the case is interesting. The woman was exceptionally intelligent and independent, and apparently managed her own fields. Whilst working in the paddy (rice) crops about six weeks before, she stooped and her cornea impinged on a piece of stubble (rice or possibly other stalk). At the time she was treated in her own house, it is said, by tobacco juice and opium water. It was very painful, which is not to be wondered at, and she sought the advice of a local mission dispensary doctor who treated her for some time. The condition got worse and being anxious for further advice, she asked her son to bring her to Madras. This fixes the nature of the implantation and the duration of development.

\section{Treatment and Duration of the Condition under Treatment}

After removal of the slough the floor of the ulcer was cauterised with pure carbolic. Thereafter atropine was regularly employed, and the ulcer touched, about twice weekly, with tincture of iodine. Potassium iodide was exhibited in 30 grain doses per diem by the mouth, and iodine given intravenously in dilute solution, in 0.25 grain doses twice weekly for four weeks. Locally magnesium sulphate inrigations, hot fomentations, yellow oxide of mercury and dionine wefe employed. The hypopyon rapidly disappeared, but the ulcer was slow to heal and the cicatricial tissue did not harden into a safe scar till three weeks after admission. She was discharged on September 9, 1928, with 6/18 vision in that eye.

\section{Bacteriological Report}

The fungus belongs to the Aleuriosporineae of the genus Glenospora described by Berkeley and Curtis, 1876, as having the following characters. Aleuriosporineae without conidiophores, with simple or appendiculate spores and pale and dark hyphae. The Aleuriospores become dark and are situated acropleurogenously, i.e., situated at the end on dark or light hyphae, but are small, being generally $6-4 \mu$ in diameter and rarely $11-5 \mu$.

In Pollacci and Nannizzi's paper on "Pathogenic mycetoma of men and animals " it is mentioned that Morax found Glenospora graphii in a case of mycosis of the cornea in 1910. Pinoy determined his cultures to be Verticillium graphii, Harz et Bezold, a species which Vuillemin afterwards assigned to the Glenospora. The authors state that probably several other cases announced by the generic name of mycosis of the eye, without determining the mycelium, may have been caused by the Glenospora graphii. 
They note that Bianchini, during inquiries made in the Botanical Institute at Siena, found this species on the remains of exhumed corpses and that the patient described by Morax dealt with hides.

Coloured illustrations representing the growth as it appeared on various media, and the efflorescence, are not sent herewith as they would probably cost much to reproduce. Col. Acton has given me a copy of the original plates for the museum of the Government Ophthalmic Hospital, Madras, and I propose to send a duplicate to the Ophthalmological Department, London School of Tropical Medicine and Hygiene.

\title{
REFERENCES.
}

Morax, V.-Mycose de la cornée causée par le verticillium graphii. Ann d'Ocul., Vol. CXLIV, p. 323, 1910.

Vuillemin, P.-Sur un champignon parasite de l'homme, Glenospora graphii (Siebenmann). Comp. Rend. Acad. d. Sc., Vol. CLIV, p. 141, 1912.

Bianchini, G.-I miceti del cadavere umano. Atti d. R. Accad. d. Fisiocrit. in Siena, s.9, Vol. XV, p. 173, 1923-24.

Pollacci, G. and Nannizzi, A.-I miceti patogeni dell'uomo e degli animali. Siena, 1924.

\section{THE OPHTHALMOSCOPIC PICTURE OF NAEVUS (MELANOMA) CHOROIDEAE}

\author{
BY \\ KENNETH B. JOHNSTON \\ MONTREAL
}

THE object of this paper is to report three cases of naevi of the choroid, seen clinically, and to offer an explanation of their varying appearances.

I wish, here, to thank Dr. A. Fuchs for his interest as well as for his permission to publish the following three clinical cases which are from Professor Meller's Clinic in Vienna. Acknowledgment is also due to Prof. E. and Dr. A. Fuchs for their kindness in allowing me to study their pathological slides from nine cases of naevi.

The choroidal naevus is an important anomaly of pigmentation of the choroid. It has been extensively studied histologically and reported on by numerous authors, but few clinical reports can be found in the literature. Foster Moore ${ }^{1}$ describes four cases of melanoma of the choroid, one of which he examined histologically. He publishes clinical drawings and gives an extensive bibliography of previously reported cases. He says, "In size they varied from about one half the area of the optic disc to about four times its area. They were roughly circular, or oval in outline. The edges were everywhere quite definite without being quite hard and sharp. There was no fading off into the surrounding fundus, nor was there 